\title{
Lämpöyrittäjyyden kannattavuus lämmönostajan ja -myyjän sekä metsänomistajan näkökulmasta
}

\author{
Tiina Sauvula-Seppälä ${ }^{1}$ \\ ${ }^{1)}$ Seinäjoen ammattikorkeakoulu, maa- ja metsätalouden yksikkö, Tuomarniementie 55, 63700 Ähtäri. \\ Tiina.sauvula-seppala@seamk.fi
}

\section{Tiivistelmä}

Tutkimuksessa tarkasteltiin Etelä-Pohjanmaan metsäkeskuksen alueella toimivien lämpöyrittäjien toiminnan kannattavuutta nettotulojen perusteella. Nettotulojen laskentaa varten selvitettiin keskimääräinen tulo- ja kustannusjakauma. Lämpöyrittäjien raaka-aineen hankinnan osalta selvitettiin kannattaako metsänomistajan myydä energiapuuta lämpöyrittäjille. Lisäksi tutkimuksessa verrattiin lämpöyrittäjän myymän lämmön hintaa öljy- sähkö ja kaukolämpöön.

Tutkimuksen perusjoukon muodostivat kaikki Etelä-Pohjanmaan metsäkeskuksen toimialueen lämpöyrittäjät. Kaikille alueella toimiville lämpöyrittäjille $(\mathrm{N}=53)$ lähetettiin postikysely tammikuussa 2009. Kyselyyn vastasi 22 lämpöyrittäjää, jotka huolehtivat yhteensä 31 lämpölaitoksesta. Lämpölaitokset jaettiin tarkastelussa tehon mukaan neljään ryhmään, joille laskettiin keskimääräiset vuotuiset nettotulot. Energiapuun myynnin kannattavuuden laskennassa käytettiin Tantun, ym. (2004) esittämää metsänomistajan energiapuun myynnin yleiskannattavuutta kuvaavaa laskentamallia. Laskentamallissa vähennettiin energiapuun myyntituloista ja kestävän metsätalouden rahoitustuista (kemera) energiapuunhankinnan kulut. Lisäksi tutkimuksessa verrattiin kahdeksan lämpöyrittäjän myymän lämmön hintaa sekä näiden keskiarvoa öljy- sähkö- ja kaukolämmön hintaan.

Tulosten perusteella lämmöntuottamisen kulut olivat keskimäärin $44 € / \mathrm{MWh}$ ja tulot keskimäärin $56 € / \mathrm{MWh}$. Hieman yli puolet, eli $23 € / \mathrm{MWh}$, tuotantokuluista muodostui kiinteän polttoaineen hankinnasta, haketuksesta ja kaukokuljetuksesta. Lämmönmyynti on lämpöyrittäjille taloudellisesti kannattavaa. Suurimmissa (>1000 kW) lämpölaitoksissa lämpöyrittäjän nettotulot olivat keskimäärin $29000 €$ vuodessa. Pienimmissä $(<200 \mathrm{~kW})$ laitoksissa lämmönmyynnin vuosittaiset nettotulot olivat keskimäärin hieman yli $4000 €$ vuodessa. Lämmönmyynnin nettotulot eivät kuitenkaan kerro lämpöyrittäjien todellista tuloa, koska lämmönmyyntitulojen lisäksi lämpöyrittäjät saavat puunmyyntituloja sekä korvausta laitoksen valvonnasta ja huollosta. Lämpöyrittäjien energiapuusta maksama hinta mahdollistaa nuoren metsän kunnostuskohteiden hakkuut. Metsänomistajan energiapuun myynnin nettotulot koneellisessa korjuussa olivat keskimäärin $9 € / \mathrm{MWh}$. Ilman kemera -tukea nettotulot olivat keskimäärin $2 € / M W h$. Vuonna 2006 lämpöyrittäjien myymä lämpö oli $34 € / M W h$ edullisempaa kuin sähköllä tuotettu lämpö, $32 € / \mathrm{MWh}$ edullisempaa kuin öljyllä tuotettu lämpö ja $3 € / \mathrm{MWh}$ edullisempaa kuin kaukolämpö. 


\section{Johdanto}

Suomen kansallisen ilmasto- ja energiastrategian mukaan uusiutuvan energian osuus pyritään nostamaan 38 prosenttiin energian loppukulutuksesta vuoteen 2020 mennessä. Tavoitteiden saavuttamiseksi hallitus korostaa, että maaseudulla tulee hyödyntää hajautettua, paikallisiin ja uusiutuviin energianlähteisiin perustuvaa energiantuotantoa (Maaseutu...2009). Paikallisten raaka-aineiden hyödyntäjinä ja lämmönmyyjinä lämpöyrittäjät vastaavat hallituksen tavoitteisiin.

Lämpöyrittäjän liikeidea on tuottaa lämpöä hankkimallaan polttoaineella ja myydä tuotettu lämpö asiakkaalle. Lämpöyrittäjän toimenkuvaan kuuluu myös lämmöntuottamiseen käytettävien laitteiden huoltotoimenpiteet ja valvonta. Lämmönostajan omistaessa lämmöntuottamiseen tarvittavat laitteet, maksaa lämmönostaja lämpöyrittäjälle tuotetusta energiasta. Hinnassa on yleensä huomioitu laitoksen huollosta, korjauksesta ja valvonnasta aiheutuneet kustannukset. Lämpöyrittäjän omistaessa lämmöntuottamiseen tarvittavat laitteet, maksaa lämmönostaja tavalla tai toisella lämpöyrittäjälle laitteiston investointikustannukset (Suhonen 2005).

Suomessa on harjoitettu 1990-luvulta lähtien lämpöyrittäjyystoimintaa (Ojarinta ym. 2007). Lämpöyrittäjien vastuulla olevien lämpölaitosten määrä on kasvanut vuosien 1992-2008 aikana kolmesta lämpölaitoksesta (Nikkola \& Solmio 2005) 423 lämpölaitokseen (Solmio \& Alanen 2009). Lämpöyrittäjien hoitamista lämpölaitoksista $28 \%$ on aluelämpölaitoksia ja loput kohteet ovat kiinteistökohtaisia (Solmio \& Alanen 2009). Kunnat ovat lämpöyrittäjien suurin asiakasryhmä, mutta viime aikoina lämmöntoimitussopimuksia on tehty yhä enemmän yksityisten kiinteistönomistajien kanssa (Ojarinta ym. 2007). Pääosa lämpöyrittäjien hoitamista lämpölaitoksista on lämmönostajien rakennuttamia ja omistamia, mutta yhtä useammin investoinnin tekee lämpöyrittäjä. Yli puolet uusista lämpölaitoksista on lämpöyrittäjien investoimia (Ojarinta ym. 2007).

Lämpöyrittäjien hoitamista lämpölaitoksista $41 \%(173 \mathrm{kpl})$ toimii Länsi-Suomen läänissä (Solmio \& Alanen 2009) ja näistä 71 kappaletta sijaitsee Etelä-Pohjanmaan metsäkeskuksen toimialueella (Energiarekisteri 2007). Etelä-Pohjanmaan metsäkeskuksen alueella on paljon maa- ja metsätaloutta, joten lämpöyrittäjyys on nähty mahdollisuutena ansaita lisätuloja. Maanviljelijän työ sitoo usein yrittäjän omalle paikkakunnalle, joten lämpökeskuksen valvonta ei hankaloita muiden töiden tekemistä (Rintamäki 2008). Ensimmäiset lämpöyrittäjät ovat aloittaneet toimintansa 1990-luvun alkupuolella (Energiarekisteri 2007). Lämpöyrittäjyystoiminta on kehittynyt alueella vuosien saatossa ja toiminta on laajentunut lämmönmyynnin lisäksi koneurakointiin ja raaka-aineiden jatkojalostukseen.

Tässä tutkimuksessa tarkastellaan Etelä-Pohjanmaan metsäkeskuksen alueella toimivien lämpöyrittäjien toiminnan kannattavuutta nettotulojen perusteella. Nettotulojen laskentaa varten selvitetään keskimääräinen tulo- ja kustannusjakauma. Lämpöyrittäjien raaka-aineen hankinnan kannalta selvitetään kannattaako metsänomistajan myydä energiapuuta lämpöyrittäjille. Myös lämpöyrittäjyyden jatkuvuuden kannalta tutkitaan onko lämpöyrittäjän myymä lämpö hinnaltaan kilpailukykyistä muihin lämmitysmuotoihin verrattuna.

\section{Aineisto ja menetelmät}

\section{Aineiston keruu}

Tutkimuksen perusjoukon muodostivat kaikki Etelä-Pohjanmaan metsäkeskuksen toimialueen lämpöyrittäjät. Kaikille alueella toimiville lämpöyrittäjille $(\mathrm{N}=53)$ lähetettiin postikysely tammikuussa vuonna 2009. Kyselyyn vastaamatta jättäneitä lämpöyrittäjiä tavoiteltiin vielä puhelimitse ja muistutettiin vastaamaan kyselyyn. Kyselyyn vastasi 22 lämpöyrittäjää, jotka huolehtivat yhteensä 31 lämpölaitoksesta. Tutkimukseen hyväksyttiin kaikki palautetut kyselylomakkeet, vaikka kysely oli täytetty vain osittain.

\section{Tutkimusmenetelmät}

Lämpöyrittäjien lämmönmyynnin kannattavuutta tarkasteltiin nettotulojen avulla. Nettotulojen laskentaa varten selvitettiin lämmönmyynnin tulot ja lämmöntuottamisen kustannukset. Lämpölaitokset jaettiin tarkastelussa tehon mukaan neljään ryhmään, joille laskettiin keskimääräiset vuotuiset nettotulot sekä nettotulot myytyä energiayksikköä kohden. Yritystoimintaa pidettiin taloudellisesti kannattavana, jos toiminnan nettotulot olivat positiiviset. Lämpöyrittäjien lainanhoitokulut laskettiin lämpöyrittäjien ilmoittamista lämpölaitosten ja lämmönjakeluverkostojen hankintahinnoista, joista oli vähennetty saatu investointituki ja mahdolliset liittymismaksut. Lainanhoitokulujen laskennassa käy- 
tettiin yrittäjien ilmoittamia laina-aikoja ja korkoja. Lämpölaitoksilla ja lämmönjakeluverkostolla ei oletettu olevan jäännösarvoa.

Metsänomistajan energiapuun myynnin yleiskannattavuutta tarkasteltiin Tantun, ym. (2004) esittämän laskentamallin avulla. Laskentamallissa yleiskannattavuutta tarkastellaan vähentämällä energiapuun myyntituloista ja kestävän metsätalouden rahoitustuista (kemera) energiapuunhankinnan kulut. Laskennassa metsänomistaja maksaa kaato-kasauksen ja metsäkuljetuksen sekä tapauksesta riippuen haketuksen ja kaukokuljetuksen. Metsänomistaja saa tuloja energiapuun myynnistä ja kemera-tuista, toteutusselvitystä lukuun ottamatta. Energiapuun koneellisten ja manuaalisen korjuukustannusten (Lauhanen 2009) sekä kemera-tukien laskeminen edellytti tyypillisen energiapuun korjuukohteen määrittämistä Etelä-Pohjanmaan metsäkeskuksen toimialueella. Mäntymaan (2007) mukaan tyypillinen kohde sijaitsee kuivahkolla kankaalla, leimikon koko on noin 3,7 ha, energiapuukertymä 32 $\mathrm{m}^{3} /$ ha ja poistettujen runkojen keskikoko $29 \mathrm{dm}^{3}$. Pääpuulaji leimikoissa on tyypillisesti mänty (50 \%). Metsäkuljetusmatka on keskimäärin 280 metriä ja kaukokuljetusmatka 40 km.

Kahdeksan lämpöyrittäjän myymän lämmön hintaa sekä näiden keskiarvoa verrattiin kevyen polttoöljy (Öljyalan palvelukeskus 2009) -, sähkö- ja kaukolämmön hintaan. Öljylämmityksessä oletettiin kattilan hyötysuhteen olevan $85 \%$. Kaukolämmön keskihintana käytettiin suurelle kerrostalolle myydyn lämmön keskihintaa (Tilastokeskus 2009a). Sähkölämmityksen keskihinta käytettiin pienelle ja keskisuurelle teollisuudelle myydyn sähkön hintaa, joka sisälsi sähköenergian, siirtomaksun ja verot (Tilastokeskus 2009b).

\section{Tulokset}

\section{Lämpöyrittäjien tulo- ja kustannusjakauma sekä yritystoiminnan kannattavuus}

Energiankulutuksen mukaista kulutusmaksua lämpöyrittäjät saivat vuosina 2006 ja 2007 keskimäärin $31 € / \mathrm{MWh}$ ja kiinteää maksua 13,1 €/MWh. Lämpöyrittäjät saivat muusta liiketoiminnasta tuloja keskimäärin 12,2 €/MWh (Kuva 1). Lämpöyrittäjien muuta liiketoimintaa olivat energiapuun- ja hakkeenmyynti, haketus ja hakkeen kuljetus. Kokonaistulot olivat keskimäärin 56,2 €/MWh.

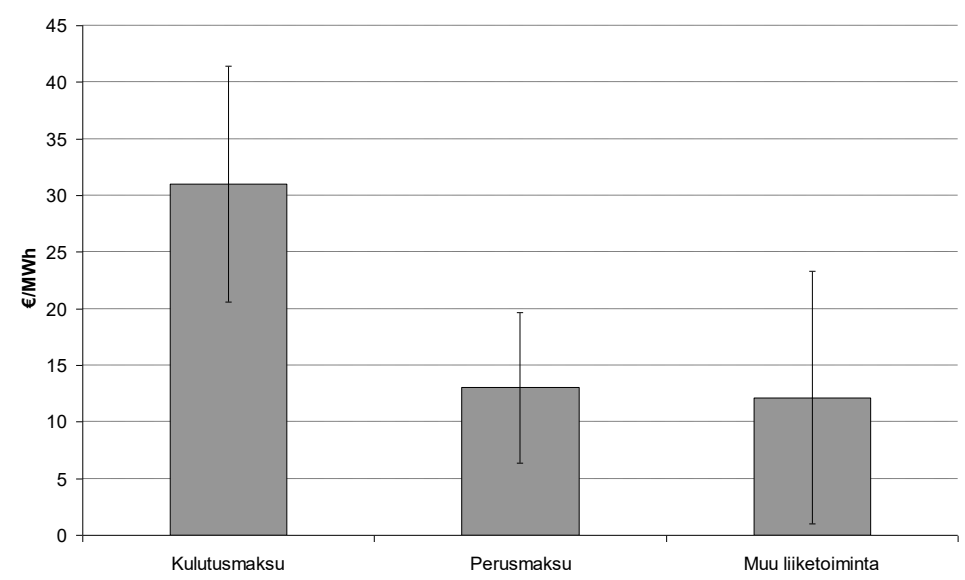

Kuva 1. Lämpöyrittäjien keskimääräiset tulot myytyä energiayksikköä kohden (€/MWh) vuosina 2006 ja 2007. Kuvassa on myös esitetty tulojen keskihajonta.

Lämpölaitoksen lainanhoitokulut olivat vuosina 2006 ja 2007 keskimäärin 9,5 €/MWh ja lämmönjakeluverkoston 3,3€/MWh. Polttoöljyn käyttökulut olivat noin $1 € / M W h$. Kiinteän polttoaineen hankintaan lämpöyrittäjät käyttivät keskimäärin $15,8 € / \mathrm{MWh}$ ja energiapuun haketukseen ja kuljetukseen 7,4 $€ / M W h$ (Kuva 2). Lämpölaitoksen huolto ja toimintahäiriöistä aiheutuneet kulut pitävät sisällä henkilöstökulut, korjaus, huolto ja muut kalustokulut. Näihin kuluihin lämpöyrittäjiltä meni keskimäärin 4 $€ / M W h$. Lisäksi lämpöyrittäjillä oli muita kuluja noin $2,7 € / M W h$. Lämmöntuottamisen kulut olivat lämpöyrittäjillä keskimäärin 43,8 €/MWh. 


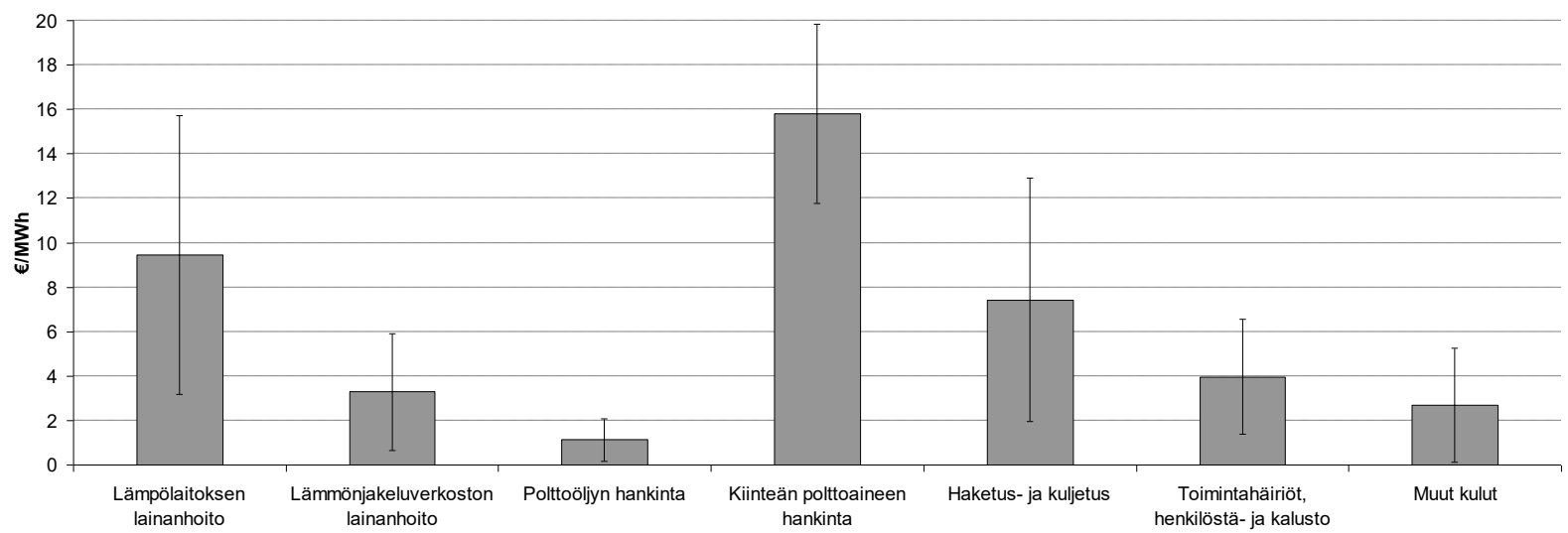

Kuva 1. Lämpöyrittäjien keskimääräiset menot vuosina 2006 ja 2007. Menot on laskettu myytyä energiayksikköä kohden (€/MWh). Kuvassa on myös esitetty menojen keskihajonta.

Lämpöyrittäjien vuoden nettotulot kasvavat lämpölaitoksen tehon kasvaessa (Kuva 3). Suurimman teholuokan lämpölaitoksessa nettotulot ovat keskimäärin noin $28500 €$ vuodessa ja pienimmän teholuokan laitoksissa keskimäärin hieman yli $4000 €$ vuodessa. Tarkasteltaessa nettotuloja myytyä energiayksikköä kohden, nettotulot pienenevät lämpölaitoksen tehon kasvaessa. Suuriman teholuokan lämpölaitoksessa nettotulot myytyä energiayksikköä kohden ovat hieman alle $5 € / \mathrm{MWh}$ ja pienimmässä teholuokassa $28 € / \mathrm{MWh}$.

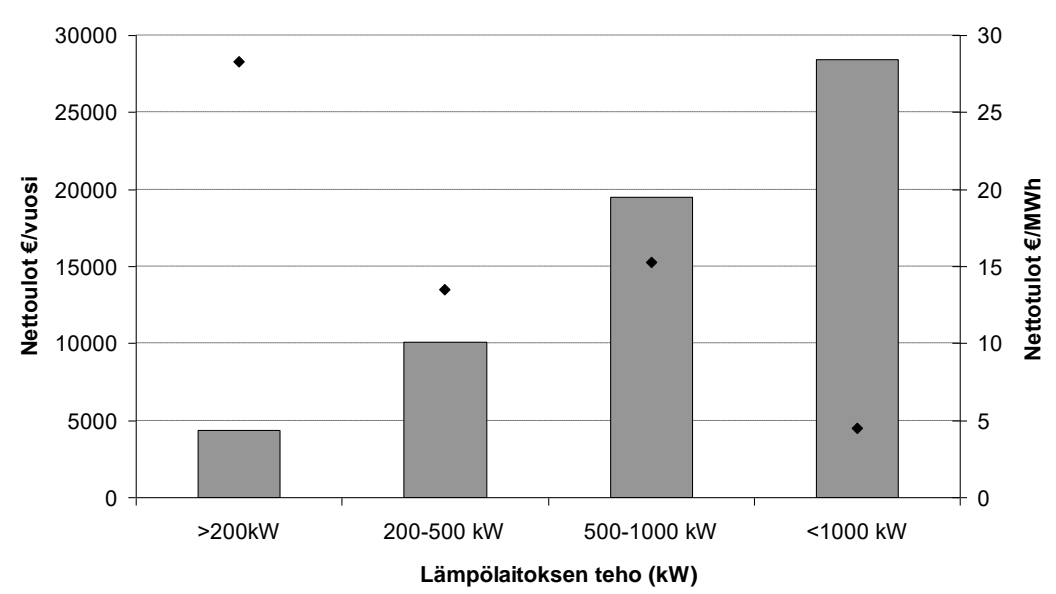

Kuva 3. Lämpöyrittäjien keskimääräinen vuotuinen nettotulo ja nettotulo myytyä energiayksikköä kohden (€/MWh) eri teholuokan ( $k W$ ) lämpölaitoksissa.

\section{Energiapuun myynnin kannattavuus lämpöyrittäjälle metsänomistajan näkökulmasta}

Kemera -tuki huomioiden, metsänomistajan kannattaa myydä energiapuuta kaikille laskennassa mukana oleville lämpöyrittäjälle. Metsänomistajan ei kannata myydä energiapuuta kolmelle lämpöyrittäjälle, mikäli myyjä ei saa kemera-tukea. Itse omistamassaan laitoksessa toimivat lämpöyrittäjät pystyivät laskennallisesti maksamaan energiapuusta paremman hinnan verrattuna lämmönostajan omistamassa laitoksessa toimiviin lämpöyrittäjiin. Tässä tutkimuksessa lämpöyrittäjät 2,3 ja 4 toimivat lämmönostajan omistamassa lämpölaitoksessa (Kuva 4).

Metsänomistajan energiapuun myynnin nettotulot koneellisessa korjuussa olivat keskimäärin 9 $€ / M W h$. Ilman kemera -tukea nettotulot olivat keskimäärin $2 € / M W h$. Energiapuun korjuu miestyönä oli metsänomistajalle heikommin kannattavaa kuin koneellinen korjuu. Nettotulot olivat miestyönä keskimäärin $3 € / M W h$ pienemmät kuin koneellisessa korjuussa. 


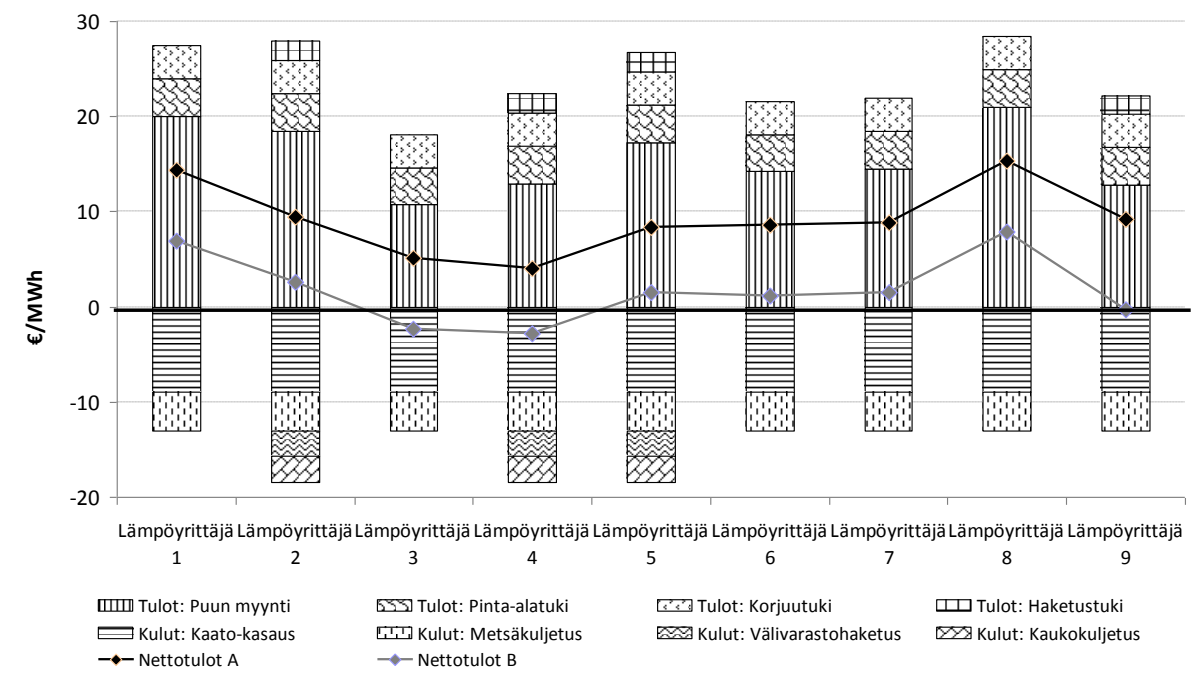

Kuva 4. Kuvassa on esitetty metsänomistajan tulot energiapuun myynnistä ja kemera -tuista sekä energiapuun hankintakulut. Nettotulo A kuvaa metsänomistajan nettotuloa, kun energiapuun myyntituloista ja kemera-tuista on vähennetty energiapuun hankintakulut. Nettotulo B kuvaa metsänomistajan nettotuloja, jos kemera-tukea ei olisi myönnetty.

\section{Lämpöyrittäjän myymän lämmön hinta verrattuna muihin lämmitysmuotoihin}

Sähkölämmitys on ollut koko tarkastelujakson ajan huomattavasti kalliimpaa kuin lämpöyrittäjien myymä lämpö. Lämpöyrittäjien myymän lämmön keskihintaan verrattuna sähkölämmitys on ollut 21$38 € / M W h$ kalliimpaa. Öljylämmityksen hinta on nousut erityisesti 2004 vuodesta eteenpäin. Tarkastelujakson alussa öljylämmitys on ollut hieman lämpöyrittäjien myymää lämpöä edullisempaa. Tilanne on kuitenkin muuttunut vuonna 2000, jonka jälkeen lämpöyrittäjien myymä lämpö on ollut huomattavasti edullisempaa. Esimerkiksi vuonna 2004 lämpöyrittäjien myymä lämpö oli $15 € / \mathrm{MWh}$ edullisempaa verrattuna öljylämmitykseen. Lämpöyrittäjien tuottama lämpö oli myös kaukolämpöön verrattuna keskimäärin edullisempaa. Keskimääräinen hintaero oli kuitenkin noin $2 € / \mathrm{MWh}$ ja kahden lämpöyrityksen (yritykset 1 ja 7) tapauksessa myyty lämpöenergia oli kaukolämpöä kalliimpaa. Sen sijaan yritysten 5,6 ja 8 myymä lämpö oli huomattavasti edullisempaa (Kuva 5).

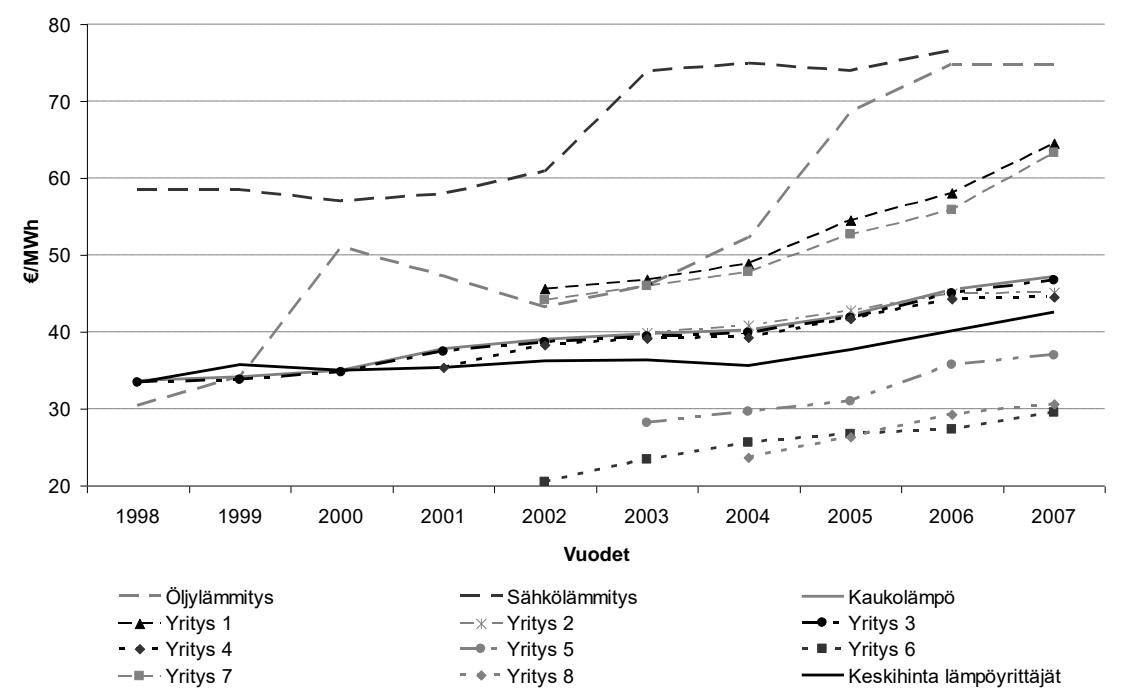

Kuva 5. Sähkö-, öljy ja kaukolämmityksen sekä kahdeksan lämpöyrittäjän myymän lämmön hintakehitys vuosina 1998-2007 (huomioi y-akselin aloituskohta).

\section{Tulosten tarkastelu}

Lämpöyrittäjyystoiminta alkoi 1990-luvulla pienten kyläkoulujen lämmittämisestä. Lämpölaitosten koko ja lämpöyrittäjyyden liikevaihto on kasvanut voimakkaasti 1990-luvulta. Lämpöyrittäjien keskimääräiset nettotulot eri teholuokan lämpölaitoksia vaihtelivat $4300-28500 €$ vuodessa. Suu- 
rimmat nettotulot olivat isoimman teholuokan laitoksissa. Näissä laitoksissa lämpöyrittäjänä toimii yleensä osuuskunta, joten nettotulon jakajana on useita jäseniä. Pienissä laitoksissa lämpöyrittäjät toimivat pääasiassa yksin, joten lämmönmyynnin nettotulot jakaa vain yksi henkilö.

Yksin nettotulojen tarkastelu ei kerro lämpöyrittäjyyden kannattavuudesta yrittäjän näkökulmasta, koska lämmönmyyntitulojen lisäksi lämpöyrittäjä saa korvausta lämpölaitoksen valvonnasta, huoltotoimista sekä puunmyyntituloja. Myös osuuskuntien vuoden nettotulojen tarkastelu on harhaanjohtavaa, koska yleensä lämpöyrittäjinä toimivat osuuskunnat palauttavat ylijäämäpalautuksina mahdollisen voiton osuuskunnan jäsenille toimitetun energiamäärän mukaan. Osuuskunnan tarkoituksena ei ole sijoittajien voiton maksimointi (Kokkonen \& Lappalainen 2005).

Lämmöntuottamisen kulut olivat lämpöyrittäjillä keskimäärin 43,8 €/MWh ja tuloja lämpöyrittäjät saivat keskimäärin 56,2 $€ / M W h$. Yli puolet kuluista eli $23 € / \mathrm{MWh}$ muodostui kiinteän polttoaineen hankinnasta, haketuksesta ja kaukokuljetuksesta. Työtehoseuran julkaisemassa lämpöyrittäjien valtakunnallisessa kannattavuustarkastelussa keskimääräiset polttoaineen hankintakulut olivat hieman alle $18 € / \mathrm{MWh}$. Valtakunnallisesta tutkimuksesta ei voida erottaa polttoaineen hankintahintaa ja haketuksen sekä kaukokuljetuksen kustannuksia (Solmio \& Tuomi 2007). Etelä-Pohjanmaan metsäkeskuksen alueella toimivat lämpöyrittäjät käyttävät hieman enemmän rahallisia panoksia raaka-aineen hankintaa kuin valtakunnallisesti keskimäärin.

Kilpailu energiapuusta tulee tulevaisuudessa kiristymään. Lämpöyrittäjien energiapuunhankintaa voi helpottaa heidän maksama hyvä hankintahinta energiapuulle. Mäntykuitupuun hankintahinta oli Etelä-Pohjanmaan metsäkeskuksen alueella vuosina 2006-2007 keskimäärin $28 € / \mathrm{m}^{3}$ (Metsäntutkimuslaitos 2009). Lämpöyrittäjät maksoivat tuolloin energiapuusta tienvarteen toimitettuna keksimäärin $16 € / \mathrm{MWh}$ eli lähes saman hinnan kuin kuitupuuta ostavat yritykset. Lämpöyrittäjien maksamaa energiapuun hintaa tarkastellessa tulee kuitenkin muistaa, että moni lämpöyrittäjä korjaa omasta metsästä raaka-aineen ja maksaa sille mahdollisimman korkeaa hintaa.

Lämpöyrittäjien maksama hinta energiapuusta mahdollistaa nuoren metsän kunnostuskohteiden hakkuut niin ettei metsänomistajalle synny kuluja. Nuoren metsän kunnostushakkuita pidetään yleisesti taloudellisesti kannattamattomina (Niemistö 2005), joten nettotulojen ollessa positiiviset voi metsänomistaja olla tyytyväinen saamaansa tuottoon. Tämän tutkimuksen perusteella metsänomistajan saadessa energiapuun myyntitulojen lisäksi kemera -tuet, kannatti metsänomistajan myydä energiapuuta kaikille tutkimuksessa mukana olleille lämpöyrittäjille. Myös ilman kemera -tukia energiapuun myynti oli kannattavaa suurimmalle osalle laskennassa mukana olleille lämpöyrittäjille. Tutkimuksessa oli havaittavissa, että lämmönostajan laitoksessa toimivien lämpöyrittäjien maksukyky puusta oli hieman heikompi kuin omassa laitoksessa toimivien lämpöyrittäjien.

Etelä-Pohjanmaalla metsäkeskuksen alueella toimivilla lämpöyrittäjillä on hyvät edellytykset laajentaa toimintaansa, koska alueen asukkailla on positiivinen mielikuva lämpöyrittäjistä. Laukan (2009) mukaan Etelä-Pohjanmaan metsäkeskuksen alueen asukkaista 78 \% ostaisi lämmön ennemmin paikalliselta lämpöyrittäjältä kuin suurilta yrityksiltä. Myös Riepon ja Solmion (2008) tekemän kyselyn perusteella pientaloasukkaita kiinnostaisi ostaa lämpöä lämpöyrittäjiltä, mutta lämpö ei saa maksaa enempää kuin nykyisellä lämmitysjärjestelmällä tuotettu lämpö. Lämpöyrittäjien myymä lämpö oli huomattavasti edullisempaa kuin öljyllä tai sähköllä tuotettu lämpö. Lämpöyrittäjien myymä lämpö oli myös hieman edullisempaa kuin kaukolämmön keskihinta.

\section{Johtopäätökset}

Tämän tutkimuksen perusteella lämmönmyynti on lämpöyrittäjille taloudellisesti kannattavaa, mutta voidaan pohtia lämpöyrittäjien toiminnan laajentuessa ja työntarpeen kasvaessa onko lämpöyrittäjyys enää sivuelinkeino kaikille yrittäjille ja saavatko yrittäjät riittävän suuren korvauksen työstään. Erityisesti pienen kokoluokan lämpölaitoksissa nettotulot eivät ole suuret. Lämpöyrittäjyyden kannattavuutta arvioitaessa tule kuitenkin muistaa, että lämmönmyynnin nettotulot eivät kuvaa lämpöyrittäjien todellista nettotuloa, koska lämmönmyyntitulojen lisäksi lämpöyrittäjät saavat tuloja puunmyynnistä sekä korvausta lämpölaitoksen valvonta ja huollosta.

Uusia uhkakuvia lämpöyrittäjyystoiminnalle saattaa tulevaisuudessa aiheuttaa kiristynyt kilpailu energiapuusta. Jo nyt Etelä-Pohjanmaan metsäkeskuksen alueella toimivien lämpöyrittäjien kiinteän polttoaineen hankinta muodostaa suurimman kuluerän. Lämpöyrittäjät maksavat tällä hetkellä energiapuusta kilpailukykyistä hintaa, joka mahdollistaa energiapuun saatavuuden ainakin toistaiseksi. 
Lämpöyrittäjien energiapuusta maksama hinta mahdollistaa nuoren metsän kunnostuskohteiden hakkuut, jopa niin että metsänomistajalle kertyy hakkuusta tuloja.

Lämpöyrittäjien myymä lämpö on hinnaltaan huomattavasti edullisempaa kuin öljy- ja sähkölämmitys. Edullisen hinnan lisäksi lämpöyrittäjien toiminnalla on positiivisia aluetaloudellisten vaikutuksia kuten parantaa alueen työllisyyttä ja energiaomavaraisuutta sekä lisää kunnan verotuloja. Näiden positiivisten alueellisten seurannaisvaikutusten myötä voidaankin pohtia tarvitsisiko paikallisesti tuotetun lämmön edes olla hinnaltaan halvinta.

\section{Kirjallisuus}

Energiarekisteri. 2007. Lähde Esa Koskiniemi Etelä-Pohjanmaan metsäkeskus.

Kokkonen, A. \& Lappalainen, I. 2005. Hakelämmöstä yritystoimintaa. Pohjois-Karjalan ammattikorkeakoulu, Motiva Oy \& Työtehoseura. s 83.

Lauhanen, R. 2009. Kemera-tukien vaikutus nuoren metsien hoidon kannattavuuteen eri kauppavaihtoehdoissa...case of Etelä-Pohjanmaa. Kehittyvä metsäenergia -seminaari. 18.11.2009, Seinäjoki.

Laukka, P. 2009. Metsäenergian käyttö yhteiseksi asiaksi, Kansalaisten käsitykset, odotukset ja mielipiteet metsäenergiasta Etelä-Pohjanmaan metsäkeskuksen alueella. Seinäjoen ammattikorkeakoulu. Maa- ja metsätalouden yksikkö, Ähtäri. s. 71.

Maaseutu ja hyvinvoiva Suomi. 2009. Valtioneuvoston maaseutupoliittinen selonteko eduskunnalle. Maaseutupolitiikan yhteistyöryhmän julkaisuja 8/2009.[www-dokumentti]. Saatavissa:

http://www.maaseutupolitiikka.fi/files/987/Maaseutu_ja_hyvinvoiva_Suomi.pdf [Viitattu 29.11.2009]

Metsäntutkimuslaitos. 2009. Puukauppa. Metinfo. [www-dokumentti]. Saatavissa:

http://www.metla.fi/metinfo/tilasto/puukauppa/. [Viitattu 8.4.2009]

Mäntymaa, S. 2007. Korjuujäljen seuranta energiapuun korjuukohteissa. Seinäjoen ammattikorkeakoulu. Maaja metsätalouden yksikkö, Ähtäri. s. 36.

Niemistö, P. 2005. Metsän käsittely. Teoksessa: Hynynen, J. Valkonen, S. ja Rantala, S (toim.) Tuottava metsänkasvatus.

Nikkola, A. \& Solmio, H. 2005. Lämpöyrittäjätoiminta vuonna 2004. Työtehoseuran metsätiedote 694.

Ojarinta, P. Puhakka, A. Tuomi, S. \& Solmio, H. 2007. Lämpöliiketoiminnan sopimusmallien ja liiketoiminnan taloudellisen kannattavuuden tutkimus ja kehittäminen. Teoksessa: Alakangas, E (toim.) Puupolttoaineiden pientuotannon ja -käytön panostusalue. Teknologiakatsaus 208/2007. S. 211-221. [www-julkaisu]. Saatavissa: http://www.tekes.fi/julkaisut/Pienpuu_vuosikatsaus_2007.pdf. [Viitattu 2.12.2008]

Rieppo, K. \& Solmio, H. 2008. Pientaloasiakkaista lämpöyrittäjille kasvumahdollisuuksia. Työtehoseuran tutkimuksen tiedote, luonnonvara-ala: metsä 5/2008 (721) s.8.

Rintamäki, J. 2008. Lämmönostajien asiakastyytyväisyyskysely lämpöyrittäjien toiminnasta Etelä-Pohjanmaan metsäkeskuksen toimialueella. Seinäjoen ammattikorkeakoulu. Maa- ja metsätalouden yksikkö, Ähtäri. s. 53.

Solmio, H. \& Alanen, V-M. 2009. Lämpöyrittäjätoiminta vuonna 2008. Työtehoseuran tutkimuksen tiedote, luonnonvara-ala: metsä 7/2009 (733) s.4.

Solmio, H. \& Tuomi, S. 2007. Lämpöyrittäjien kustannukset ja toiminnan kannattavuus. Työtehoseuran tutkimuksen tiedote, luonnonvara-ala: metsä 5/2007 (711) s.4.

Suhonen, N. 2005. Hakelämpö kunnissa - hinnoitteluperusteet ja riskit. [www-julkaisu]. Saatavissa: http://metsa.pkamk.fi/t_k_toiminta/biomateriaali/Hakel\%C3\%A4mp\%C3\%B6kunnissa_\%20Niko_Suhonen\%20 pdf.pdf. [Viitattu 23.3.2009]

Tanttu, V. Ahtikoski, A. \& Sirén, M. 2004. Korjuuvaihtoehtojen kannattavuus metsänomistajalle nuoren metsän harvennuksessa hankintakaupalla. Metsätieteen aikakausikirja 4/2004 s. 509-525

Tilastokeskus. 2009a. Kaukolämmön hinta kuluttajatyypeittäin.[www-dokumentti]. Saatavissa: http://www.stat.fi/til/ehkh/2009/02/ehkh_2009_02_2009-09-17_tie_001.html. [Viitattu 30.11.2010]

Tilastokeskus. 2009b. Sähkön hinta kuluttajatyypeittäin. [www-dokumentti]. Saatavissa: http://www.stat.fi/til/ehkh/2009/02/ehkh_2009_02_2009-09-17_tie_001.html. [Viitattu 30.11.2010]

Öljyalan palvelukeskus. 2009. Öljy- ja kaasualan tilasto. Lähde Jyrki Pohjola [sähköpostiviesti]. 